\title{
Occupational Therapy Practice Patterns In Two Rural States: Does The College Experience Influence Rural Employment Choice?
}

Debra J.Hanson

University of North Dakota

Janet S. Jedlicka

University of North Dakota

Nicole C. Harris

University of North Dakota

Marilyn G. Klug

University of North Dakota

Follow this and additional works at: https://encompass.eku.edu/jote

Part of the Occupational Therapy Commons

\section{Recommended Citation}

Hanson, D. J., Jedlicka, J. S., Harris, N. C., \& Klug, M. G. (2018). Occupational Therapy Practice Patterns In Two Rural States: Does The College Experience Influence Rural Employment Choice?. Journal of Occupational Therapy Education, 2 (3). https://doi.org/ $10.26681 /$ jote. 2018.020307 


\title{
Occupational Therapy Practice Patterns In Two Rural States: Does The College Experience Influence Rural Employment Choice?
}

\begin{abstract}
An online survey was conducted of 225 occupational therapy (OT) practitioners living in the rural states of North Dakota and Wyoming to explore practice patterns and the influence of the college experience on employment choice. Findings showed that rural practitioners had greater variability of hours spent working (5.5 more hours per week, $\mathrm{p}=.028)$, and one more work location on average $(\mathrm{p}=.006)$. Therapists in urban settings spent $15 \%$ more time in fieldwork education than their rural counterparts $(\mathrm{p}=.021)$. Rural practice choice was influenced by participation in Level I and Level II fieldwork $(\mathrm{p}=.002)$ but not by loan debt. Study implications for academic programs include focusing on multiple areas of practice in the curriculum design, and exposure of students to rural practitioners and rural practice examples/experiences. Recommendations were made for rural fieldwork educator training and employer support of rural fieldwork education. Further study of the experience of working within a rural practice context as a student and OT practitioner are recommended, including variables impacting rural practitioner work with fieldwork students, and student interest in rural fieldwork placement.
\end{abstract}

\section{Keywords}

Rural health services, occupational therapists, fieldwork, workforce manpower

\section{Creative Commons License}

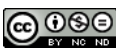

This work is licensed under a Creative Commons Attribution-Noncommercial-No Derivative Works 4.0 License.

\section{Acknowledgements}

Thank you to the occupational therapists from North Dakota and Wyoming who contributed to this study. 


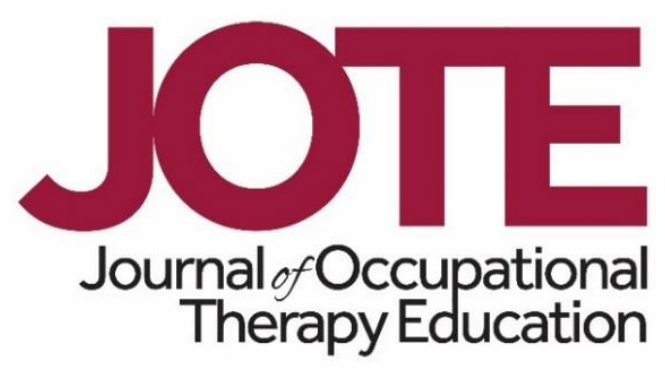

Volume 2, Issue 3

\title{
Occupational Therapy Practice Patterns in Two Rural States:
}

Does the College Experience Influence Rural Employment Choice?

Debra J. Hanson, PhD, OTR/L, FAOTA, Janet S. Jedlicka, PhD, OTR/L, FAOTA,

Nicole C. Harris, MOT, OTR/L, and Marilyn G. Klug, PhD

University of North Dakota

United States

\begin{abstract}
An online survey was conducted of 225 occupational therapy (OT) practitioners living in the rural states of North Dakota and Wyoming to explore practice patterns and the influence of the college experience on employment choice. Findings showed that rural practitioners had greater variability of hours spent working (5.5 more hours per week, $\mathrm{p}=.028)$, and one more work location on average $(\mathrm{p}=.006)$. Therapists in urban settings spent $15 \%$ more time in fieldwork education than their rural counterparts $(p=.021)$. Rural practice choice was influenced by participation in Level I and Level II fieldwork $(p=.002)$ but not by loan debt. Study implications for academic programs include focusing on multiple areas of practice in the curriculum design, and exposure of students to rural practitioners and rural practice examples/experiences. Recommendations were made for rural fieldwork educator training and employer support of rural fieldwork education. Further study of the experience of working within a rural practice context as a student and OT practitioner are recommended, including variables impacting rural practitioner work with fieldwork students, and student interest in rural fieldwork placement.
\end{abstract}

\section{INTRODUCTION}

Rural settings in the United States and other countries have a sparse distribution of occupational therapy (OT) practitioners, usually clustering in more urban/suburban areas (Wilson, Lewis, \& Murray, 2009; Playford, Larson, \& Wheatland, 2006). There is limited information about the nature of OT practice in rural versus urban areas and much of what is known comes from literature outside of the United States (Brockwell, Wielandt, \& Clark, 2009; Roots \& Li, 2013; Wielandt \& Taylor, 2010). For example, rehabilitation practice in rural areas in Australia occurs in a variety of workplace settings 
with a diverse caseload and a high client-to-therapist ratio, requiring therapists to have a wide set of clinical and professional skills (Boshoff \& Hartshorne, 2008; Devine, 2006). A study of rural practice in western Canada yielded similar findings to practice in Australia in that the majority of participants worked as the sole therapist in a generalist practice, typically serving a large and diverse caseload across a large geographic region. Respondents reported a number of unique training needs pertaining to their rural practice profile and the authors suggested that findings had implications for educational programs (in addressing unique training needs), funding agencies, and health human resource planning for underserviced areas (Winn, Chisolm, \& Hummelbrunner, 2014).

Little is known about the impact of fieldwork education on OT practitioner choice of rural practice in the United States (US), but Australian and Canadian studies support the positive impact of undergraduate rural exposure to improving students' perceptions towards and decisions to work in rural practice (MacRae, van Diepen, \& Paterson, 2007; Playford et al. 2006; Winn et al., 2014). Findings from an Australian study support the influence of rural roots on student consideration of rural employment, but also demonstrate the influence of educational experiences within the OT program, good fieldwork experiences, and inspiring fieldwork supervisors on rural employment choice (McAuliffe \& Barnett, 2010). Study results further suggested that despite initial inclinations, students' perceptions towards rural practice could be positively influenced over the course of their academic study. Participation in rural fieldwork placements that fosters participation in the local community appear to be particularly influential for individuals not originally from rural areas (Winn et al., 2014; Wolfgang, Dutton \& Wakely, 2014).

Students who are provided financial incentives such as travel and housing or loan debt forgiveness may be more inclined to participate in a rural fieldwork experience (Tran et al., 2008). Loan debt repayment has also been found to influence the recruitment of healthcare providers to practice in rural practice areas (Daniels, Vanleit, Skipper, Sanders \& Rhyne, 2007), but the specific impact of loan debt on OT recruitment to work in the states of North Dakota (ND) and Wyoming (WY) is unexplored.

The purpose of this study was to understand the practice patterns of OT practitioners in the rural states of ND and WY and the influence of the college experience on practice choice. More specifically:

1) Is rural practice for OT practitioners more varied in time (hours per week, percent time in areas of direct patient care, administration, education of OT students, other areas), number of employers and number of work locations than urban practice?

2) How does the college experience of fieldwork (Levels I and II locations and their influence), as well as college debt (having a student loan and its amount) impact an OT practitioner's choice of working in a rural versus urban area? 


\section{METHODS}

\section{Survey Development and Implementation}

A Qualtrics survey was developed based on literature review and modifications of existing surveys that had been tested for validity and reliability (Keane, Smith, Lincoln, Wagner, \& Lowe, 2008; Larson, Hart, Muus, \& Geller 1999). Specific areas used from these surveys included background/demographic information, employment descriptions, and questions related to education and professional development. The developed survey was piloted by eight OT practitioners in ND (two faculty members and six therapists with rural practice experience). Questions were modified to increase conciseness, clarify ambiguity, and minimize any duplication. The survey was checked for content validity by four reviewers (a faculty member and three practitioners; one of the practitioners was working in a rural setting.) Approval was obtained from the University of North Dakota (UND) Institutional Review Board (IRB) for the online study. Table 1 has a list of the survey questions used for this analysis. The format of the questions included Likert scale, multiple choice, and text boxes to clarify or provide additional information. The results were split randomly into two groups to ensure validity and consistency of the data; there were no significant differences found between the two groups of participants (using chi-square and independent t-tests). The alpha level set for statistical analysis was 0.05 .

Table 1

\section{Survey Questions}

1. What is your current age? (in years)

2. What gender do you identify yourself as?

3. Please select the items that best describe your race/ethnicity.

4. What is the postal (zip) code of your current residence?

5. Identify your work location, number of employers, work locations and practice classifications.

6. Identify your percentage of working hours spent in administration, direct patient care, education (of OT/OTA students) and other roles.

7. Considering all positions you currently fill, how long is your average work week in hours?

8. What are the occupational therapy (OT) and non-OT related academic degrees you have completed?

9. What are the occupational therapy assistant (OTA) and non-OTA related academic degrees you have completed?

10. Did you have a full-time Level I fieldwork experience in a rural setting (community less than 10,000 population) as part of your academic preparation?

11. Did the rural Level I fieldwork experience influence your final employment location?

12. Did you have a full-time Level II fieldwork experience in a rural setting (community less than 10,000 population) as part of your academic 
preparation?

13. Did the rural Level II fieldwork influence your final employment location?

14. Do you take students for Level I Fieldwork?

15. Do you take students for Level II Fieldwork?

16. What category best represents your total earnings as an occupational therapist or occupational therapy assistant in the last year?

17. When you graduated with your occupational therapy degree, did you have any educational loan debt?

18. What category best represents your total loan debt at the time of graduation?

19. Did your loan debt influence your employment choice?

Work load was first measured by the average hours the respondent worked per week, as well as average percent of their weekly time spent in four areas: direct patient care, administration, fieldwork education, and other. Number of employers and number of work locations were investigated. Additional questions pertained to fieldwork experience: if they had a rural field work Level I or II placement, and how it influenced their choice of a rural or urban position. Level I fieldwork was represented by short-term experiences designed to enrich didactic course work through direct observation and participation in selected aspects of the OT process, whereas Level II fieldwork represented an in-depth experience delivering OT services to clients for an extended (8 - 12 week) timeframe (ACOTE, 2012). Respondents were asked whether they currently take students for Level I or II fieldwork. In addition, respondents were asked to disclose a category best representing their yearly salary, if they had student loan debt when they graduated, and if so, the amount of debt and whether it influenced their choice of rural or urban position.

\section{Participants}

Occupational therapists and occupational therapy assistants (OTAs) licensed in ND and WY were the target group for this study. In July of 2015, there were 735 licensed OT practitioners in ND; 171 were licensed as OTAs and 564 were licensed OTs. This compares with WY having a total of 515 license holders, including 149 OTAs and 366 OTs. Initially emails were sent to all licensed therapy personnel (OTs and OTAs) in each state and data collected from January through February of 2015. Due to a low response rate of $8 \%$, the IRB proposal was amended and approved to allow researchers to request program directors of OT and OTA education programs in ND and WY to email the link of the Qualtrics survey to their graduates. Additional survey distribution occurred at fall conferences sponsored by the ND and WY occupational therapy associations. The second wave of data collection occurred from July through September of 2015. Information regarding the study and how the data would be used was provided in the introduction. Participants were informed that by completing the survey they were providing consent to participate in this research. 


\section{Respondents and Analysis}

In total, 245 people completed all or part of the survey, a 19.6\% response rate. Postal code was obtained to determine rural versus urban status. There were 225 who provided a ZIP code for their residence which we translated into Rural Urban Commuting Area (RUCA) codes. Three categories, urban (120; 53.3\%), large rural (55; $24.4 \%)$, and small or isolated rural $(50 ; 22.2 \%)$ were used.

Rural educational experiences were tested for association with rural status using chisquare analyses. A comparison of average hours per week and percent time in direct patient care between urban, large rural, and small/isolated rural was performed using one-way Analysis of Variance (ANOVA) and independent t-tests for direct patient care. As the other work load variables had a large positive skew, non-parametric KruskalWallis Chi-Square was used to test for distribution differences between rural status.

\section{RESULTS}

Nearly all respondents (95.6\%) were female and white (98.2\%). The average age was 40.8 years (S.D. $=11.4$ ) and ranged from 23 to 67 . Respondents had been in practice for an average of 15.6 years (S.D.=11.0) ranging from 1 to 36 years. Most were OTs $(80.9 \%)$, but the sample was representative of the proportion of OT and OTAs practicing in each state.

Table 2 shows average indicators of workloads for the 225 OT/OTAs. One-way ANOVAs indicated no significant differences in average hours per week $(p=.102)$ or percent of time spent in direct patient care $(p=.058)$. However, independent $t$-tests showed the average hours of those in small/isolated areas (mean=43.03, S.D.=12.19) was significantly more than those from urban or large rural areas (mean 38.51, S.D.=10.76) ( $t=2.05, p=.028)$. Further, those in urban areas had significantly less time spent in direct patient care (mean $=74.64$, S.D. $=21.35$ ) than those from rural areas (mean=66.03, S.D.=33.63) $(\mathrm{t}=2.19 \mathrm{p}=.015)$. Percent time spent in administration was not significantly different between urban, large rural, and small/isolated rural $(p=.394)$ practitioners. Urban dwelling OT/OTAs spent $13 \%$ of their time, on average, in fieldwork education (Level I and II combined) which was significantly higher than $6 \%$ for rural OT/OTAs $(p=.021)$. The average percent of time spent in other areas significantly increased from $5 \%$ in urban to $7 \%$ in large rural to $8 \%$ in small/isolated rural $(p=.048)$. There was no significant difference in number of employers. The average number of work locations was significantly higher $(m e a n=3)$ for large rural and small/isolated rural compared to urban (mean $=2, \mathrm{p}=.006$ ). 
Table 2

Comparison of Average Work Load Variables by Urban/Rural Status

\begin{tabular}{|c|c|c|c|c|c|c|c|c|}
\hline Variable & Location & $\mathbf{N}$ & Mean & $\begin{array}{l}\text { St. } \\
\text { Dev. }\end{array}$ & Min & Max & Statistic & $p$ \\
\hline \multirow{3}{*}{$\begin{array}{l}\text { Hours per } \\
\text { Week }\end{array}$} & Urban & 90 & 38.08 & 11.94 & 2.50 & 70 & 2.31 & .102 \\
\hline & Large Rural & 44 & 39.41 & 7.87 & 15 & 50 & & \\
\hline & $\begin{array}{l}\text { Small/Isolated } \\
\text { Rural }\end{array}$ & 31 & 43.03 & 12.19 & 20 & 84 & & \\
\hline \multirow{3}{*}{$\begin{array}{l}\text { \% Time in } \\
\text { Direct } \\
\text { Patient } \\
\text { Care }\end{array}$} & Urban & 112 & 66.03 & 33.63 & 0 & 100 & 2.88 & .058 \\
\hline & Large Rural & 50 & 77.46 & 17.31 & 20 & 100 & & \\
\hline & $\begin{array}{l}\text { Small/Isolated } \\
\text { Rural }\end{array}$ & 49 & 71.76 & 24.66 & 0 & 100 & & \\
\hline \multirow{3}{*}{$\begin{array}{l}\text { \% Time in } \\
\text { Admini- } \\
\text { stration }\end{array}$} & Urban & 112 & 15.72 & 23.99 & 0 & 100 & 1.86 & .394 \\
\hline & Large Rural & 50 & 10.20 & 12.85 & 0 & 50 & & \\
\hline & $\begin{array}{l}\text { Small/lsolated } \\
\text { Rural }\end{array}$ & 49 & 14.43 & 18.02 & 0 & 95 & & \\
\hline \multirow{3}{*}{$\begin{array}{l}\text { \% Time in } \\
\text { Education }\end{array}$} & Urban & 112 & 13.15 & 25.20 & 0 & 100 & 7.71 & .021 \\
\hline & Large Rural & 50 & 5.69 & 10.42 & 0 & 55 & & \\
\hline & $\begin{array}{l}\text { Small/Isolated } \\
\text { Rural }\end{array}$ & 49 & 5.89 & 16.35 & 0 & 100 & & \\
\hline \multirow{3}{*}{$\begin{array}{l}\text { \% Time in } \\
\text { Other } \\
\text { Work }\end{array}$} & Urban & 112 & 5.10 & 12.59 & 0 & 80 & 6.08 & .048 \\
\hline & Large Rural & 50 & 6.65 & 12.70 & 0 & 70 & & \\
\hline & $\begin{array}{l}\text { Small/Isolated } \\
\text { Rural }\end{array}$ & 49 & 7.93 & 12.55 & 0 & 50 & & \\
\hline \multirow{3}{*}{$\begin{array}{l}\text { Number of } \\
\text { Employers }\end{array}$} & Urban & 113 & 1.51 & 1.28 & 1 & 7 & 3.04 & .218 \\
\hline & Large Rural & 49 & 1.67 & 1.30 & 1 & 7 & & \\
\hline & $\begin{array}{l}\text { Small/lsolated } \\
\text { Rural }\end{array}$ & 45 & 1.87 & 1.52 & 1 & 7 & & \\
\hline \multirow{3}{*}{$\begin{array}{l}\text { Number of } \\
\text { Work } \\
\text { Locations }\end{array}$} & Urban & 114 & 1.97 & 1.61 & 1 & 7 & 10.13 & .006 \\
\hline & Large Rural & 49 & 2.51 & 1.93 & 1 & 7 & & \\
\hline & $\begin{array}{l}\text { Small/Isolated } \\
\text { Rural }\end{array}$ & 47 & 2.81 & 1.87 & 1 & 7 & & \\
\hline
\end{tabular}

* One-way ANOVA and F statistic used for hours per week and direct patient care. Kruskal-Wallis Chi-Square used for other variables.

The associations between fieldwork education experiences and rural status are summarized in Table 3 . The percentages of individuals living in small/isolated rural settings who had completed a Level I fieldwork in a rural setting were low $(29.4 \%)$, as were the percentages experiencing a Level II fieldwork in a rural area (36.1\%) whereas $59.8 \%$ of those living in an urban area had experienced a Level I fieldwork in an urban area and $61.1 \%$ had experienced a Level II fieldwork in an urban area. Of the 102 
OT/OTAs who had completed a Level I fieldwork in rural areas, $29 \%$ still lived in those areas while only $16 \%$ of those participating in an urban Level 1 fieldwork lived in those areas; a difference of $13 \%$. This was similar to OT/OTAs who completed an urban Level I fieldwork as the likelihood of ultimately practicing in an urban area increased by $15 \%$ (45\% compared to $60 \%)$.

Table 3

Association of College Education Experiences with Urban/Rural Location

\begin{tabular}{|c|c|c|c|c|c|c|c|c|}
\hline & \multicolumn{2}{|c|}{ Urban } & \multicolumn{2}{c|}{$\begin{array}{c}\text { Large } \\
\text { Rural }\end{array}$} & \multicolumn{2}{c|}{$\begin{array}{c}\text { Small/Isolated } \\
\text { Rural }\end{array}$} & \multirow{2}{*}{$\begin{array}{c}\text { Chi- } \\
\text { Square }\end{array}$} & p \\
\cline { 2 - 9 } & $\mathbf{N}$ & $\mathbf{( \% )}$ & $\mathbf{N}$ & $\mathbf{( \% )}$ & $\mathbf{N}$ & $\mathbf{( \% )}$ & \\
\hline Rural Fieldwork & & & & & & & & \\
\hline Level I Rural & 46 & $(45.1 \%)$ & 26 & $(25.5 \%)$ & 30 & $(29.4 \%)$ & 6.556 & .038 \\
\hline Level I Urban & 73 & $(59.8 \%)$ & 29 & $(23.8 \%)$ & 20 & $(16.4 \%)$ & & \\
\hline Level II Rural & 27 & $(37.5 \%)$ & 19 & $(26.4 \%)$ & 26 & $(36.1 \%)$ & 14.58 & $<.001$ \\
\hline Level II Urban & 91 & $(61.1 \%)$ & 35 & $(23.5 \%)$ & 23 & $(15.4 \%)$ & & \\
\hline Influenced & & & & & & & & \\
\hline Level I Yes & 4 & $(21.0 \%)$ & 3 & $(15.8 \%)$ & 12 & $(63.2 \%)$ & 12.66 & .002 \\
\hline Level I No & 42 & $(51.2 \%)$ & 22 & $(26.8 \%)$ & 18 & $(22.0 \%)$ & & \\
\hline Level II Yes & 6 & $(30.0 \%)$ & 4 & $(20.0 \%)$ & 10 & $(50.0 \%)$ & 2.323 & .313 \\
\hline Level II No & 21 & $(40.4 \%)$ & 15 & $(28.8 \%)$ & 16 & $(30.8 \%)$ & & \\
\hline $\begin{array}{l}\text { Had Student } \\
\text { Loan }\end{array}$ & & & & & & & & \\
\hline Yes & 73 & $(50.7 \%)$ & 31 & $(21.5 \%)$ & 40 & $(27.8 \%)$ & 6.046 & .049 \\
\hline No & 26 & $(61.9 \%)$ & 12 & $(28.6 \%)$ & 4 & $(9.5 \%)$ & & \\
\hline Loan Debt & & & & & & & & \\
\hline$<\$ 20,000$ & 24 & $(50.0 \%)$ & 7 & $(14.6 \%)$ & 17 & $(35.4 \%)$ & 4.722 & .317 \\
\hline $\begin{array}{c}\$ 20,000- \\
\$ 60,000\end{array}$ & 26 & $(44.6 \%)$ & 16 & $(27.7 \%)$ & 16 & $(27.6 \%)$ & & \\
\hline$>\$ 60,000$ & 21 & $(58.3 \%)$ & 8 & $(22.2 \%)$ & 7 & $(19.4 \%)$ & & \\
\hline Debt Influence & & & & & & & & \\
\hline Yes & 19 & $(52.8 \%)$ & 9 & $(25.0 \%)$ & 8 & $(22.2 \%)$ & 0.843 & .656 \\
\hline No & 54 & $(20.0 \%)$ & 22 & $(20.4 \%)$ & 32 & $(29.6 \%)$ & & \\
\hline
\end{tabular}

The association was stronger for OT/OTAs and their Level II fieldwork location $(p<.001)$ with over twice as many living in the same rural or urban areas as their scheduled fieldwork. Of the 102 OT/OTAs who completed Level I fieldwork in rural areas, nearly two thirds indicated this influenced their choice of where to live $(p=.002)$, however the association for 72 Level II rural fieldwork OT/OTAs influencing their choice was not significant $(p=.313)$. OT/OTAs with student loans were nearly three times as likely to live in small/isolated rural areas $(p=.049)$. But there was no significant association with the amount of student loans or if it influenced their choice. 


\title{
DISCUSSION
}

\begin{abstract}
Variability of Rural Practice
The findings support the uneven distribution of OT practitioners to population in the rural states of ND and WY. Students who acquired loan debt during their college experience were nearly three times more likely to live in small/isolated rural areas (see Table 3). It is unclear whether this is a causal factor in choosing to work in a rural area or if the individuals were already situated in a rural context and returned there after completion of education.
\end{abstract}

Although rural practitioners may have only 1-2 employers, it is clear they distribute their work differently than their urban counterparts. Individuals working in the small/isolated areas work more hours per week than those from urban or large rural areas and they spend more time in direct patient care and about the same amount of time in administrative activities as their urban counterparts (see Table 2). This suggests that a third factor, such as travel time, might account for a larger share of work hours. OT practitioners appear to address role demand by working more than 40 hours per week, a strategy that conceals the magnitude of healthcare shortages and is associated with professional burnout (Edwards \& Dirette, 2010).

Time allotted to administrative work was not statistically different despite the increases in direct patient care. This emphasizes the importance of strong skills in administration for rural practice (Wielandt \& Taylor, 2010). Although there is no difference in the number of employers (likely related to the corporate nature of much of healthcare provision in the US), those working in rural areas provided services in significantly more work locations than their urban counterparts. Similarities to rural practice in other countries are noted including the variety of workplace settings, diversity of work responsibilities and propensity to serve as a sole proprietor in rural practice (Devine, 2006; Boshoff \& Hartshorne, 2008; Winn et al., 2014). The results substantiate the unique training needs of healthcare practitioners working in rural areas within the US.

\section{Fieldwork Education and Choosing Rural Practice}

Despite the highly rural population of our study (ND and WY), and the positive influence of the rural fieldwork experience, respondents were much more likely to have experienced an urban Level I or II fieldwork than a rurally situated Level I or II fieldwork (see Table 3). This raises questions regarding the availability and popularity of rural placements for students.

A large percentage of urban therapists indicated that education of fieldwork students is a part of their role, but a lower percentage of rural practitioners included these activities in their role descriptions. The variability and overtime associated with rural practice may explain the significant difference of time spent in fieldwork education between urban and rural practitioners; rural practitioners appear to compensate for their overload in practice responsibilities by not providing fieldwork education to students. Already overworked 
and putting in overtime to handle the day-to-day responsibilities of their job, rural practitioners may decide against extending their professional commitments by assuming oversight of a student.

Time commitments aside, if rural practitioners recognize the impact of fieldwork on practice choice of students, why do they not take on the fieldwork educator role? One aspect to consider is that fieldwork educators tend to draw on their own experiences as a student to structure learning experiences for fieldwork students (Richards, 2008). Since most respondents who worked in rural areas had completed their Level II fieldwork in urban areas, it might be that they have difficulty translating how their past experience as a student could be replicated in a rural site. For example, it may be difficult for them to conceptualize how they might provide their student with the sense of "team" that they experienced in their urban fieldwork settings when the rural practice involves interaction with multiple different treatment teams.

The curriculum design of the OT academic program and how it is perceived by potential fieldwork educators may impact rural practitioner readiness to supervise fieldwork students. It is an accreditation requirement that fieldwork experiences provided are consistent with the curriculum design of the academic program (ACOTE, 2012, p. 33), and many programs employ a design that focuses on common client groupings, such as pediatric, physical disabilities or mental health populations (ACOTE, 2012). In the rural setting, such distinctions are not practical, given the variety of settings and populations addressed.

Respondents in this study who completed a rural Level II experience were not significantly influenced by the experience towards rural practice, which raises questions regarding the quality of their learning experience or the supports provided. Attention to the quality of the student learning experience is important. International researchers have found that merely completing a rural fieldwork placement does not positively influence students to work in rural areas, but a "good experience" in a rural placement along with positive role modeling does inspire students toward a rural career (McAuliffe \& Barnett, 2010).

Student interest in rural placements is influenced by the availability of supports within the rural community such as travel stipends, affordable housing and social supports as well as the quality of the fieldwork supervision provided (McAuliffe \& Barnett, 2010; Tran et al., 2008; Winn et al., 2014; Wolfgang et al., 2014). Study results revealing the prevalence of loan debt among practitioners living in small/isolated rural areas suggests that financial support could be a strong incentive for student participation in a rural fieldwork placement. However, more study is needed to untangle the impact of financial incentive and fieldwork learning experiences on rural practice choice.

\section{LIMITATIONS}

Respondents for this study were recruited through online means and from individuals present at state association meetings which might limit those individuals who were not comfortable with use of online technology or were not invested in continuing education 
through the local state associations. The response rates to survey participation were relatively low, particularly among certified occupational therapy assistants (COTAs), therefore results may not be representative of the experiences of all practitioners in the rural states of ND and WY. Data gathered reflects the self-report of respondents and may not represent the complete profile of rural practice participation. The length of the survey may have impacted response rates and user engagement in all items. In addition, it is important to note that the use of multiple statistical tests can increase the risk of Type I errors, increasing the chance of finding a statistically significant relationship between variables.

More work needs to be done in relation to the influence of rural background on fieldwork and rural practice choices. Future studies should explore rural fieldwork educator perceptions regarding student fieldwork placement and supports needed to maximize fieldwork potentials, as well as student perceptions of rural fieldwork placements. The impact of student loan debt on choice of rural fieldwork placement and rural practice also merits further study.

\section{IMPLICATIONS FOR OCCUPATIONAL THERAPY EDUCATION}

This study confirms the disparity of OT practitioner numbers in rural versus urban settings in two rural states. It also illustrates the complexity and variability of rural practice in regard to hours spent working, number of work locations, and variability of practice focus. Study results point to challenges for rural fieldwork education, including less likelihood of student participation and diminished availability of rural placements. Variability of caseloads and overtime may be barriers to rural practitioners finding time to focus on and support student learning. Due to these challenges, fieldwork educators in rural areas may need different resources and supports to undertake fieldwork education than their urban counterparts. This has implications for both academic programs and employers.

Academic programs might consider how the curriculum prepares students for the variability of rural practice. Exposure to multiple areas of practice and rural practitioners through guest lectures or field trips providing rural practice examples is recommended (Hanson \& Jedlicka, 2015). Educators should explore rural fieldwork educator perceptions of benefits and drawbacks to fieldwork placement to address perceived barriers and highlight fieldwork benefits. In view of rural practice variability, educators are advised to collaborate with fieldwork educators to develop focal points for student learning in the Level I and II fieldwork experience.

Rural health care employers interested in establishing a student program might review practitioner productivity expectations and travel requirements when overtime is common, and provide OT practitioners release time for fieldwork education. Further employer supports for rural student placement might include such incentives as housing, stipends and fostering student social connections in the rural community (Roots \& Li, 2013; Winn et al., 2014). 
There is a definite need for additional research to better understand the experiences of students and practitioners in rural settings. Qualitative research might explore factors that motivate practitioners to choose employment in a rural setting, and the experience of working within a rural practice context as a student and as a practitioner. There is a need to understand motivators and drawbacks for rural practitioners considering the fieldwork educator role, and supports desired by rural fieldwork educators to prepare for student supervision.

\section{CONCLUSION}

Results from an online survey of OT practitioners living in the rural states of ND and WY provide insightful data regarding workforce practice patterns and the influence of the college experience on employment choice. Findings demonstrate the greater variability of hours spent working and number of work locations for rural practitioners and more time spent in fieldwork education by therapists in urban settings. Study results verify the influence of participation in Level I and Level II fieldwork on rural practice choice, but do not validate loan debt as an impact factor.

Study implications for academic programs were explored including the value of focus on multiple areas of practice in the curriculum design and student exposure to rural practitioners and rural practice examples/experiences. Additional recommendations were made to support rural fieldwork education.

\section{References}

Accreditation Council for Occupational Therapy Education (ACOTE®) (2012). 2011 Accreditation Council for Occupational Therapy Education Standards and Interpretive Guide. American Journal of Occupational Therapy, 66, S6-S74. https://doi.org/10.5014/ajot.2012.66S6

Boshoff, K., \& Hartshorne, S. (2008). Profile of occupational therapy practice in rural and remote South Australia. Australian Journal of Rural Health, 16, 255-261. https://doi.org/10.1111/j.1440-1584.2008.00988.x

Brockwell, D., Wielandt, T., \& Clark, M. (2009). Four years after graduation: Occupational therapists' work destinations and perceptions of preparedness for practice. Australian Journal of Rural Health, 17, 71-76. https://doi.org/10.1111/j.1440-1584.2008/01020.x

Daniels, Z. M., Vanleit, B. J., Skipper, B. J., Sanders, M. L., \& Rhyne, R. L. (2007). Factors in recruiting and retaining health professionals for rural practice. Journal of Rural Health, 23, 62-71. https://doi.org/10.1111/j.1748-0361.2006.00069.x

Devine, S. (2006). Perceptions of occupational therapists practicing in rural Australia: A graduate perspective. Australian Occupational Therapy Journal, 53, 205-210. https://doi.org/10.1111/j.1440-1630.2006.00561.x

Edwards, H., \& Dirette, D. (2010). The relationship between professional identity and burnout among occupational therapists. Occupational Therapy in Health Care, 24, 119-129. https://doi.org/10.3109/073805709.3329610

Hanson, D., \& Jedlicka, J. (2015). Can rural fieldwork opportunities positively influence student practice choice? OT Practice,20, 16, 17-18. 
Keane, S., Smith, T. N., Lincoln, M., Wagner, S. R., \& Lowe, S. E. (2008). The rural allied health workforce study (RAHWS): Background, rationale and questionnaire development. Rural and Remote Health, 8, 1132. Retrieved from https://www.rrh.org.au/journal/article/1132

Larson, E. H., Hart, L. G., Muus, K., \& Geller, J. (1999). Content of physician assistant practice: Results from a national survey. WWAMI Rural Health Research Center Working Paper \#55. Seattle, WA: University of Washington, Department of Family Medicine.

MacRae, M., van Diepen, K., \& Paterson, M. (2007). Use of clinical placements as a means of recruiting health care professionals to underserviced areas in southeastern Ontario: Part 1 - student perspectives. Australian Journal of Rural Health, 15, 21-28. https://doi.org/10.1111/j.14401584.2007.00845.x

McAuliffe, T., \& Barnett, F. (2010). Perceptions towards rural and remote practice: A study of final year occupational therapy students studying in a regional university in Australia. Australian Occupational Therapy Journal, 57, 293-300. https://doi.org/10.1111/j.1440-1630.2009.00838.x

Playford, D., Larson, A., \& Wheatland, B. (2006). Going country: Rural student placement factors associated with future rural employment in nursing and allied health. Australian Journal of Rural Health, 14, 14-19. https://doi.org/10.1111/.1440-1584.2006.00745.x

Richards, L. F. (2008). Exploring connections between theory and practice: Stories from fieldwork supervisors. Occupational Therapy in Mental Health, 24(2), 154-175. https://doi.org/10.1080/01642120802055259

Roots, R. \& Li, L. (2013). Recruitment and retention of occupational therapists and physiotherapists in rural regions: A meta-synthesis. BMC Health Services Research, 13, 59. https://doi.org/10.1186/1472-6963-13-59

Tran, D., McGillis Hall, L., Davis, A., Landry, M. D., Burnett, D., Berg, K., \& Jaglal, S. (2008). Identification of recruitment and retention strategies for rehabilitation professionals in Ontario, Canada: Results from expert panels. BioMedical Central Health Services Research, 8, 249. https://doi.org/10.1186/1472-6963-8-249

Wielandt, P. M., \& Taylor, E. (2010). Understanding rural practice: Implications for occupational therapy education in Canada. Rural and Remote Health, 10 (3), 1488.

Wilson, R. D., Lewis, S. A., \& Murray, P. K. (2009). Trends in the rehabilitation therapist workforce in underserved areas: 1980-2000. The Journal of Rural Health, 25 (1), 26-32. https://doi.org/10.1111/j.1748-0361.2009.00195.x

Winn, C. S., Chisolm, B. A., \& Hummelbrunner, J. A. (2014). Factors affecting recruitment and retention of rehabilitation professionals in Northern Ontario, Canada: A cross-sectional study. Rural and Remote Health, 14, 2619-2626.

Wolfgang, R., Dutton, R., \& Wakely, K. (2014). Creating positive rural experiences for occupational therapy students. Australian Journal of Rural Health, 22, 204-205. https://doi.org/10.1111/ajr.12104 